\title{
Outcome Analysis of Dual Implant Osteosynthesis for Ipsilateral Proximal and Shaft Femur Fractures: Do We Need Cephalomedullary Nails?
}

\author{
Saurabh Singh ${ }^{1}$, Achyut Ravi ${ }^{1}$, Pankaj Kumar Maurya ${ }^{1}$, Rishabh Surana ${ }^{1}$, Alok Rai ${ }^{1}$ \\ 1. Orthopedic Surgery, Banaras Hindu University, Varanasi, IND
}

Corresponding author: Achyut Ravi, acyt.rvi@gmail.com

\section{Abstract}

\section{Introduction}

Most surgeons prefer a single implant for segmental proximal and diaphyseal femur fractures, although results are controversial and still no consensus for proper management is present. This prospective study analyses the functional and radiological outcome of managing 17 patients with ipsilateral shaft and proximal femur fractures by dual implant osteosynthesis at our center.

\section{Methods}

Over a two-year period, we managed 17 patients with a mean age of 35 years, with cancellous cannulated screws or dynamic hip screws for intracapsular femur fractures and improvised proximal femoral nail for extracapsular proximal femur fractures. Distal femoral locking plates or distal femoral nails were used for shaft femur fractures depending upon fracture morphology. The patients had a maximum follow-up of 18 months.

\section{Results}

A total of $80 \%$ of patients had a good functional outcome (using the Friedman-Wyman scoring system) while $60 \%$ had an excellent Harris Hip Score. The mean time taken for the bone union for proximal femur fractures was 4.75 months and for shaft femur fractures, it was 6 months.

\section{Conclusion}

We had a satisfactory functional and clinical outcome of managing these fractures with two implants, one focusing biomechanically on each fracture. This principle of dual implant osteosynthesis can reliably be used in such difficult fracture patterns and it negates the use of the single cephalomedullary nail for fixating both fractures.

Review began 06/27/2021 Review ended 07/13/2021 Published 07/25/2021

\section{(c) Copyright 2021}

Singh et al. This is an open access article distributed under the terms of the Creative Commons Attribution License CC-BY 4.0., which permits unrestricted use, distribution, and reproduction in any medium, provided the original author and source are credited.
Categories: Orthopedics, Trauma

Keywords: dual implant, osteosynthesis, femur, functional outcome, union

\section{Introduction}

The percentage of an additional proximal femur fracture accompanying a femoral shaft is approximately $1 \%-9 \%[1]$. The mechanism of injury is often attributed to high-energy trauma transferring the force to the shaft as well as proximal femur [1]. Also, in such cases, there is a reported $10 \%-30 \%$ chance of missing the proximal femur fracture at initial evaluation [2,3]. Various treatment strategies have been recommended; some authors suggest fixation with single implant, commonly cephalomedullary nails, but have reported non-union at one of the fracture sites, mostly diaphyseal fracture, in some of the patients [4]. Other authors suggest prompt surgery with priority to be given to femoral neck fracture fixation while some others advocate for fixation of the femoral shaft fracture first for providing better control of the leg during the subsequent more challenging femoral neck reduction [5-7]. Nevertheless, there is presently no consensus regarding the optimal treatment of these fractures, as to, which fracture should be fixed first and what implant to be used [8]. This prospective study reports the functional and radiological outcome analysis of dual implant osteosynthesis in managing 17 patients with ipsilateral femur shaft and proximal femur fractures.

\section{Materials And Methods}

A total of 32 patients presented to our center with ipsilateral proximal femoral and concomitant diaphyseal femur fractures, out of whom five patients had open wound at fracture site, three patients had ipsilateral tibia fracture, three patients were aged more than 60 years, two patients were deemed surgically unfit due to head injury and were conservatively managed for the time being and two patients had implant in situ and hence were excluded. 
Seventeen patients with ipsilateral shaft femur and proximal femur fractures were treated within a period of two years from 2017 to 2019 at our tertiary care center in North India. Patients were followed up at regular intervals of one, three, six years and half yearly afterwards with the maximum follow-up being 18 months. There were 13 male and 4 female patients and the mean age was 35 years. Inclusion criteria were (1) age 18 to 60 years, (2) acute trauma less than three weeks old and (3) ipsilateral proximal femur and shaft fractures. Exclusion criteria were (1) any other fractures in ipsilateral limb, (2) patients with soft tissue defects or open wound, (3) those with coagulopathy, (4) poliotic limb, (5) previously operated with or without implant in situ (6) and surgically unfit patients. All patients had a high-energy mechanism of injury ranging from road traffic accidents to falls from a height.

All patients were primarily managed following standard Advanced Trauma Life Support (ATLS) guidelines and X-rays of the injured limbs were taken along with trauma series X-rays of the chest, pelvis and cervical spine. CT scans were taken for intercondylar distal femur fractures and also for undisplaced intracapsular femur fractures if any suspicion arose regarding fracture morphology. All patients with ipsilateral proximal femur and shaft femur fractures were given proper splintage and skeletal traction and were

hemodynamically stabilized. After attaining pre-anesthetic fitness, patients were taken to surgery. Both the fractures were treated in single sitting with the shaft or distal femur fracture being fixed first and later the intracapsular or extracapsular proximal fracture.

After spinal anesthesia, patients were placed on the fracture table and surgically prepped and draped. The distal femur fracture was fixed first using the distal femur locking plate using the standard lateral approach and shaft femur fractures were fixed using distal femoral nails via a closed retrograde approach. Fixation of the distal fracture first results into sufficient traction, rotational stability and proper control of reduction for the proximal fracture. Next, the intracapsular femur fracture was fixed using standard percutaneous approach with three cancellous cannulated screws in an inverted triangle fashion or with the dynamic hip screw using the direct open lateral approach. Extracapsular proximal femur fractures were fixed using proximal femur nails.

On the second postoperative day, dressing was checked and physiotherapy started in the form of ankle, quadriceps and knee motion exercises. Suture removal was done at two weeks. After four weeks, partial weight bearing was allowed with walker support and consecutively weight bearing was increased in accordance with the progress of bone healing. Bone union was defined as bridging callus and bony trabeculations across the fracture in three out of four cortices in follow up X-rays. Parameters assessed at regular follow-ups were the Harris Hip Score, and the time of bone union of both the fractures and functional outcome using the Friedman-Wyman Scoring system $[9,10]$. Complications during the course of treatment were also noted.

Following is an example of a case: Figures $1 a-1 d$ show the pre-operative antero-posterior and lateral views of the proximal femur fracture and the shaft femur fracture. Figures $2 a, 2 b$ show the fixation of proximal femur fracture using the short proximal femoral nails and Figures $2 c, 2 d$ show fixation of the shaft femur fracture with the distal femur plate.

Statistical analysis was done using SPSS Statistics software (IBM Corp., Armonk, NY, USA). Significance was calculated based on Pearson's chi-squared test. A result was considered to be statistically significant with a p-value $<0.05$. Written informed consent was taken from patients for publication of this study and any accompanying images. 


\section{Cureus}

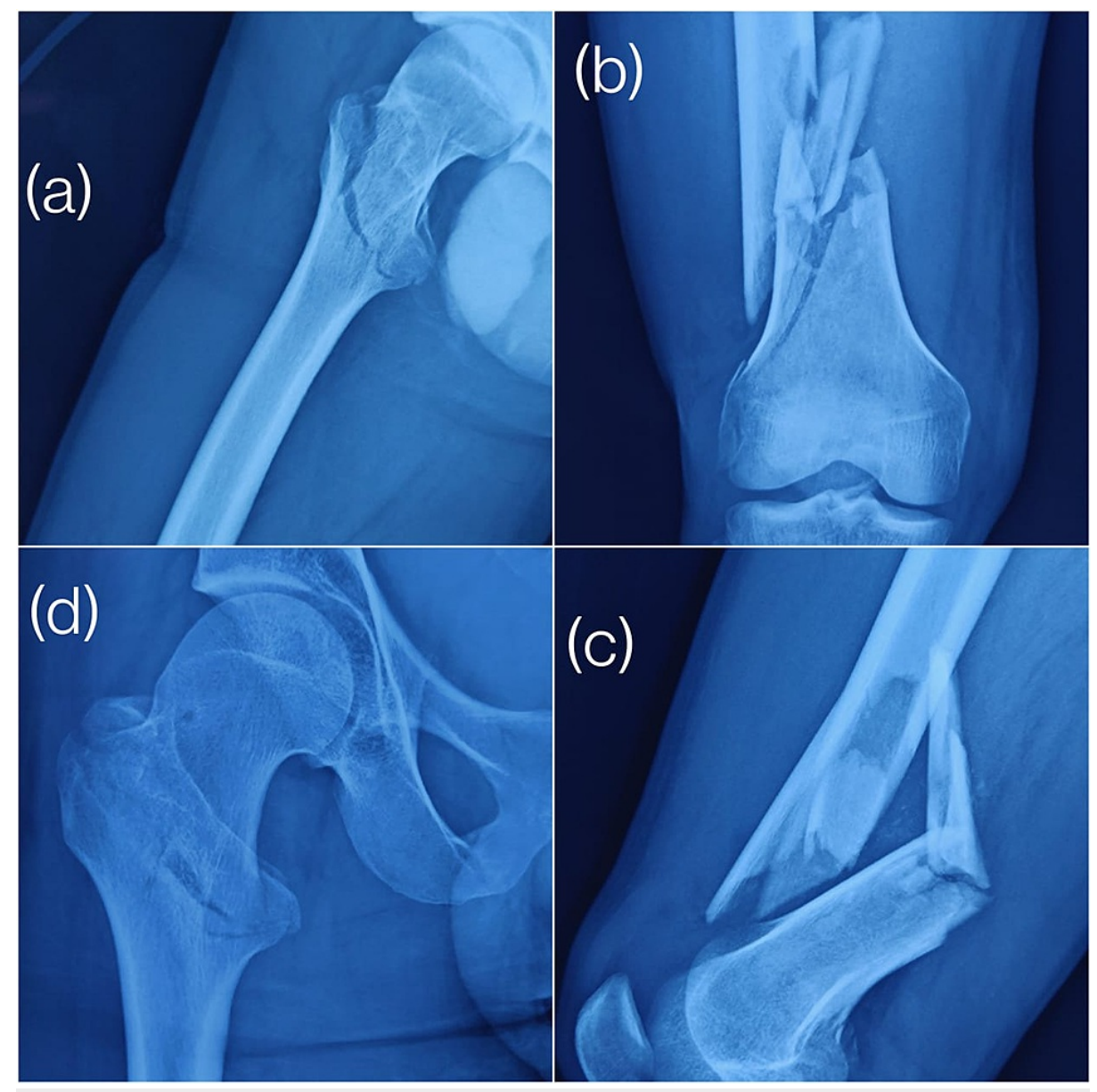

FIGURE 1: Pre-operative X-rays of a 38-year-old male

(a) Lateral view of the proximal femur fracture; (b) antero-posterior view of the shaft femur fracture; (c) lateral view of the shaft femur fracture; (d) antero-posterior view of the proximal femur fracture 


\section{Cureus}
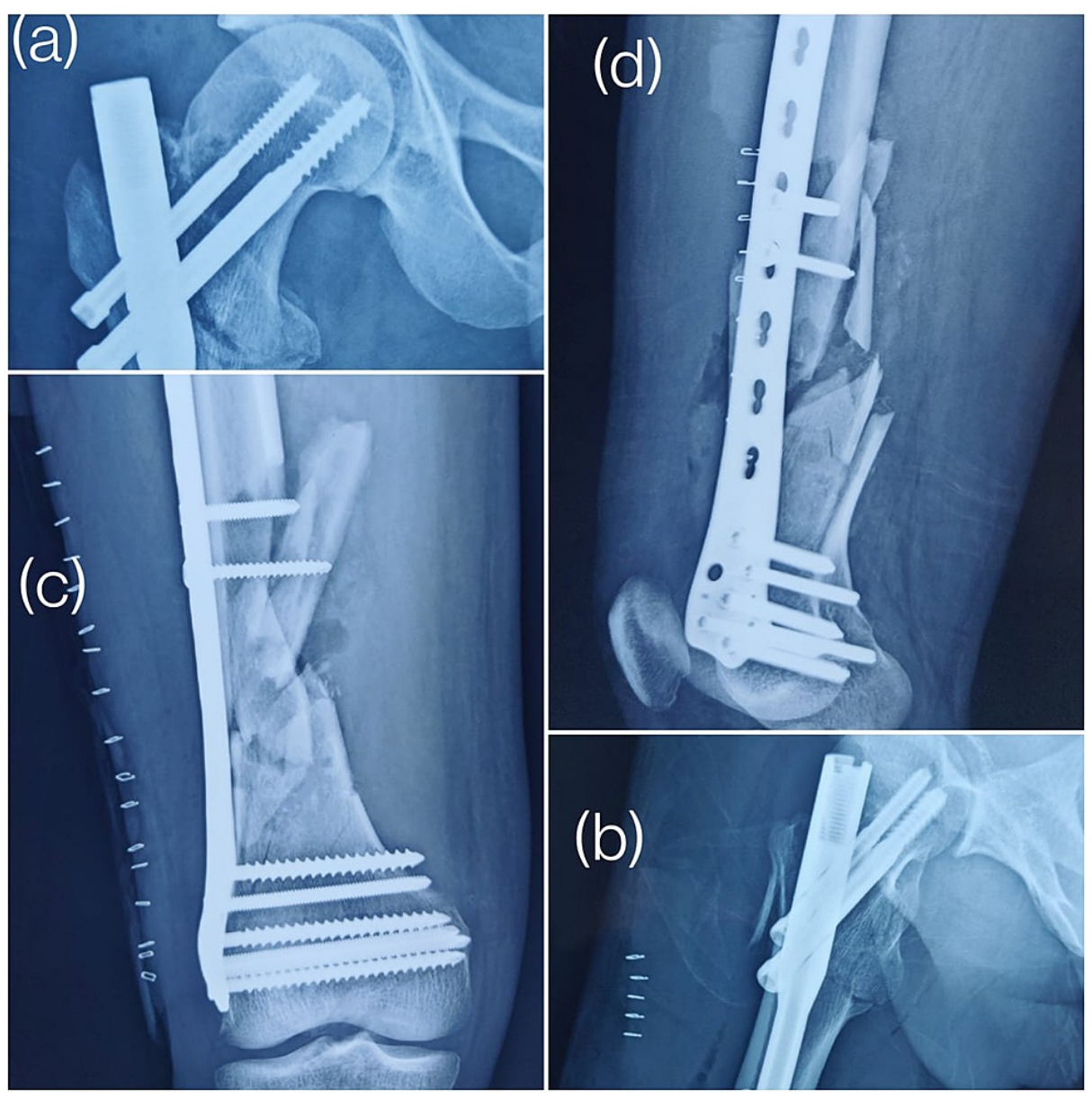

\section{FIGURE 2: Post-operative day $1 \mathrm{X}$-rays}

Immediate post-operative X-rays showing (a) an antero-posterior view of fixation of the proximal femur fracture with a short proximal femoral nail; (b) a lateral view of fixation of the proximal femur fracture with a short proximal femoral nail; (c) an antero-posterior view of fixation of the shaft femur fracture with a distal femur locking plate; (d) a lateral view of fixation of the shaft femur fracture with a distal femur locking plate

\section{Results}

Out of the total 17 patients with ipsilateral proximal and shaft femoral fractures, four patients had a combination of an intracapsular femur fracture with a distal femur fracture managed with cancellous cannulated screws and distal femoral locking plate, eight patients had extracapsular a femur fracture with a distal femur fracture managed with a short proximal femoral nail and distal femur locking plate, two patients had an intracapsular femur fracture along with a shaft femur fracture managed with cancellous cannulated screws and a distal femoral nail and three other patients had an extracapsular femur fracture with the shaft femur fracture managed with a short proximal femoral nail with a distal femoral nail.

Out of these 17 patients, 11 (64.7\%) patients had an excellent Harris Hip Score at the final follow-up, 5 (29.4\%) had good and 1 (5.8\%) patient had a fair Harris Hip Score. Regarding the functional outcome measurement of these patients done by the Friedman-Wyman scoring system, 14 (82.3\%) patients had a good functional outcome and 3 (17.6\%) patients had a fair functional outcome as mentioned in Table 1. 


\begin{tabular}{|c|c|c|c|c|c|c|c|c|}
\hline \multirow{3}{*}{$\begin{array}{l}\text { S. } \\
\text { no. }\end{array}$} & \multirow{3}{*}{ Age/sex } & \multirow{3}{*}{ Diagnosis (fracture) } & \multirow{3}{*}{$\begin{array}{l}\text { Implants } \\
\text { used }\end{array}$} & \multirow{3}{*}{$\begin{array}{l}\text { Max. follow-up period } \\
\text { (months) }\end{array}$} & \multicolumn{4}{|c|}{ Final follow-up } \\
\hline & & & & & \multirow{2}{*}{$\begin{array}{l}\text { Harris Hip } \\
\text { Score }\end{array}$} & \multirow{2}{*}{$\begin{array}{l}\text { Friedman- } \\
\text { Wyman score }\end{array}$} & \multicolumn{2}{|c|}{ Time of union } \\
\hline & & & & & & & $\begin{array}{l}\text { Proximal } \\
\text { femur }\end{array}$ & $\begin{array}{l}\text { Shaft } \\
\text { femur }\end{array}$ \\
\hline 1 & $36 / M$ & $\begin{array}{l}\text { Neck femur + Distal } \\
\text { femur }\end{array}$ & $\begin{array}{l}\text { CCS + } \\
\text { DFLP }\end{array}$ & 18 & Excellent & Good & 3 months & $\begin{array}{l}6 \\
\text { months }\end{array}$ \\
\hline 2 & $28 / M$ & $\begin{array}{l}\text { Neck femur + Distal } \\
\text { femur }\end{array}$ & $\begin{array}{l}\text { CCS + } \\
\text { DFLP }\end{array}$ & 18 & Excellent & Good & 3 months & $\begin{array}{l}9 \\
\text { months }\end{array}$ \\
\hline 3 & $30 / / \mathrm{M}$ & $\begin{array}{l}\text { Neck femur + Distal } \\
\text { femur }\end{array}$ & $\begin{array}{l}\text { CCS + } \\
\text { DFLP }\end{array}$ & 16 & Good & Good & 5 months & $\begin{array}{l}6 \\
\text { months }\end{array}$ \\
\hline 4 & $35 / \mathrm{F}$ & $\begin{array}{l}\text { Intertrochanteric + } \\
\text { Distal femur }\end{array}$ & $\begin{array}{l}\text { sPFN + } \\
\text { DFLP }\end{array}$ & 15 & Excellent & Good & 4 months & $\begin{array}{l}7 \\
\text { months }\end{array}$ \\
\hline 5 & 40/M & $\begin{array}{l}\text { Neck femur + Shaft } \\
\text { femur }\end{array}$ & $\begin{array}{l}\text { DHS + } \\
\text { DFN }\end{array}$ & 12 & Excellent & Good & 5 months & $\begin{array}{l}4 \\
\text { months }\end{array}$ \\
\hline 6 & $36 / M$ & $\begin{array}{l}\text { Intertrochanteric + } \\
\text { Distal femur }\end{array}$ & $\begin{array}{l}\text { sPFN + } \\
\text { DFLP }\end{array}$ & 13 & Excellent & Good & 7 months & $\begin{array}{l}9 \\
\text { months }\end{array}$ \\
\hline 7 & $27 / F$ & $\begin{array}{l}\text { Intertrochanteric + } \\
\text { Shaft femur }\end{array}$ & $\begin{array}{l}\text { SPFN + } \\
\text { DFN }\end{array}$ & 16 & Excellent & Good & 4 months & $\begin{array}{l}6 \\
\text { months }\end{array}$ \\
\hline 8 & $42 / \mathrm{M}$ & $\begin{array}{l}\text { Neck femur + Distal } \\
\text { femur }\end{array}$ & $\begin{array}{l}\text { CCS + } \\
\text { DFLP }\end{array}$ & 15 & Good & Fair & 5 months & $\begin{array}{l}8 \\
\text { months }\end{array}$ \\
\hline 9 & $38 / \mathrm{M}$ & $\begin{array}{l}\text { Intertrochanteric + } \\
\text { Distal femur }\end{array}$ & $\begin{array}{l}\text { sPFN + } \\
\text { DFLP }\end{array}$ & 18 & Excellent & Good & 4 months & $\begin{array}{l}7 \\
\text { months }\end{array}$ \\
\hline 10 & $35 / F$ & $\begin{array}{l}\text { Intertrochanteric + } \\
\text { Distal femur }\end{array}$ & $\begin{array}{l}\text { sPFN + } \\
\text { DFLP }\end{array}$ & 15 & Excellent & Good & 4 months & $\begin{array}{l}5 \\
\text { months }\end{array}$ \\
\hline 11 & $55 / \mathrm{F}$ & $\begin{array}{l}\text { Intertrochanteric + } \\
\text { Distal femur }\end{array}$ & $\begin{array}{l}\text { SPFN + } \\
\text { DFLP }\end{array}$ & 15 & Good & Fair & 6 months & $\begin{array}{l}6 \\
\text { months }\end{array}$ \\
\hline 12 & 29/M & $\begin{array}{l}\text { Intertrochanteric + } \\
\text { Distal femur }\end{array}$ & $\begin{array}{l}\text { sPFN + } \\
\text { DFLP }\end{array}$ & 16 & Fair & Fair & 7 months & $\begin{array}{l}6 \\
\text { months }\end{array}$ \\
\hline 13 & $35 / \mathrm{M}$ & $\begin{array}{l}\text { Intertrochanteric + } \\
\text { Shaft femur }\end{array}$ & $\begin{array}{l}\text { SPFN + } \\
\text { DFN }\end{array}$ & 14 & Good & Good & 7 months & $\begin{array}{l}7 \\
\text { months }\end{array}$ \\
\hline 14 & $30 / \mathrm{M}$ & $\begin{array}{l}\text { Intertrochanteric + } \\
\text { Distal femur }\end{array}$ & $\begin{array}{l}\text { sPFN + } \\
\text { DFLP }\end{array}$ & 14 & Excellent & Good & 7 months & $\begin{array}{l}9 \\
\text { months }\end{array}$ \\
\hline 15 & $38 / \mathrm{M}$ & $\begin{array}{l}\text { Intertrochanteric + } \\
\text { Distal femur }\end{array}$ & $\begin{array}{l}\text { SPFN + } \\
\text { DFLP }\end{array}$ & 16 & Excellent & Good & 6 months & $\begin{array}{l}5 \\
\text { months }\end{array}$ \\
\hline 16 & 40/M & $\begin{array}{l}\text { Intertrochanteric + } \\
\text { Shaft femur }\end{array}$ & $\begin{array}{l}\text { SPFN + } \\
\text { DFN }\end{array}$ & 15 & Excellent & Good & 6 months & $\begin{array}{l}4 \\
\text { months }\end{array}$ \\
\hline 17 & $35 / \mathrm{M}$ & $\begin{array}{l}\text { Neck femur + Shaft } \\
\text { femur }\end{array}$ & $\begin{array}{l}\text { DHS + } \\
\text { DFN }\end{array}$ & 13 & Good & Good & 3 months & $\begin{array}{l}7 \\
\text { months }\end{array}$ \\
\hline
\end{tabular}

\section{TABLE 1: Details of individual patients with the final follow-up score}

DFLP = distal femoral locking plate; CCS = cancellous cannulated screw; $\mathbf{S P F N}=$ short proximal femoral nail; DFN = distal femoral nail; DHS = dynamic hip screw; $M$ = male; $F$ = female

The intracapsular femur fracture was united in an average of four months with a range of three to six months. Extracapsular proximal fractures united in an average of five months with a range of four to seven months; diaphyseal fractures united in an average of 6.5 months with a range from four to nine months.

Two patients had superficial infections that resolved by antibiotics. Three patients had a delayed union at the distal femur fracture whereas their corresponding proximal fracture healed uneventfully, although none 


\section{Cureus}

of the cases progressed into non-union. No case of osteonecrosis was seen at the final follow-up in the intracapsular fractures nor were any implant failures noted.

Figure 3 shows the one-year follow-up X-ray of the aforementioned case showing union in the proximal femur fracture and union in the shaft femur fracture.

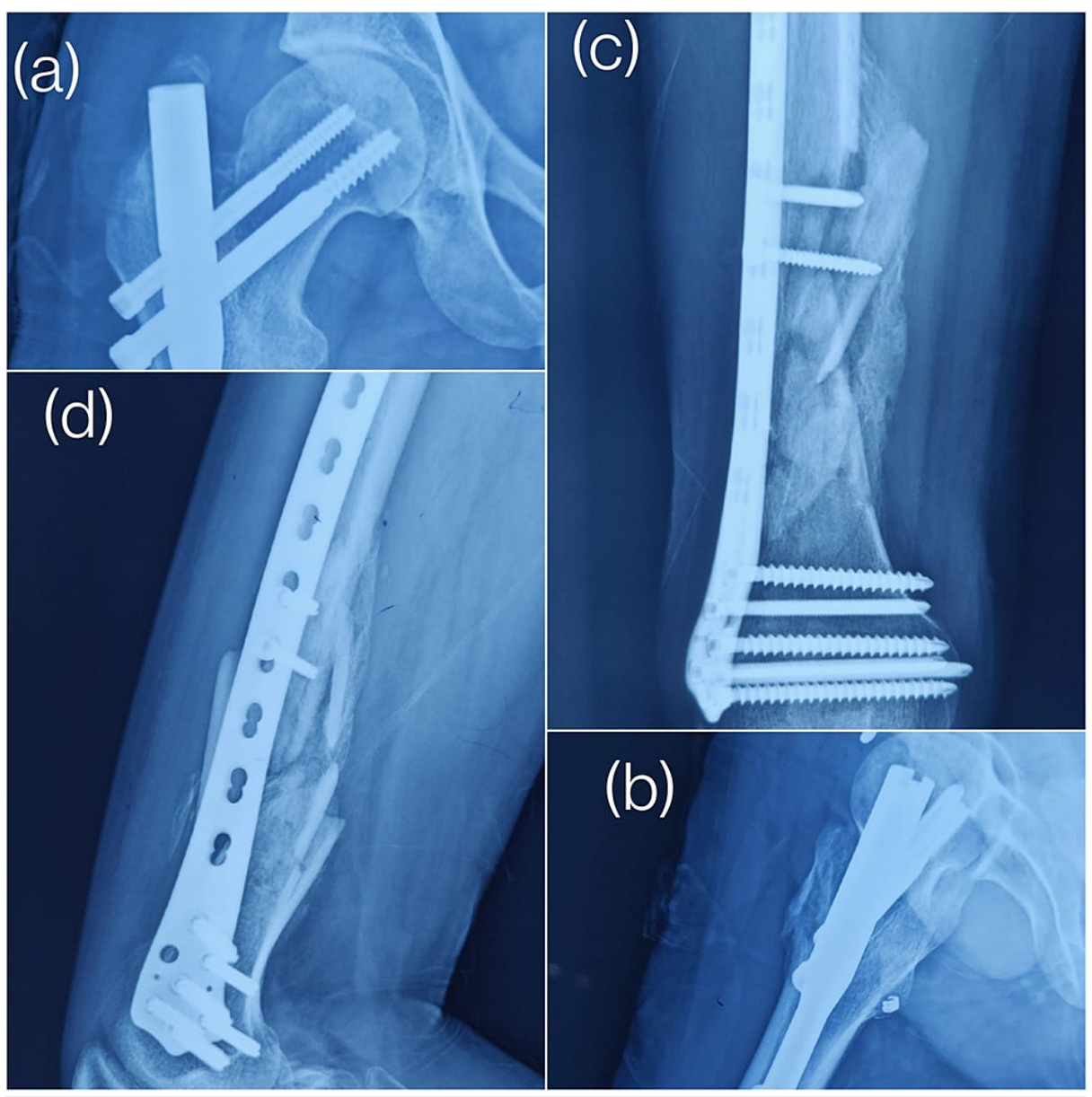

FIGURE 3: One-year follow-up X-rays

(a) Antero-posterior and (b) lateral view of the union at the proximal femur fracture. (c) Antero-posterior and (d) lateral view of the union at the shaft femur fracture

Table 2 shows the parameters used to determine the Friedman-Wyman score of these patients and Table 3 shows the individual score of all patients regarding these parameters. Table 4 shows the Harris Hip Score.

\begin{tabular}{|c|c|c|c|}
\hline & Impaired daily life activity & Pain & Loss of hip and knee range of motion \\
\hline Good & No & Nil & $<20 \%$ \\
\hline Fair & Mild & Mild-moderate & $20 \%-50 \%$ \\
\hline Poor & Moderate & Severe & $>50 \%$ \\
\hline
\end{tabular}

\section{TABLE 2: Friedman-Wyman score}




\section{Cureus}

\begin{tabular}{|c|c|c|c|c|}
\hline S. no. & Age/sex & Impairment in daily life & Pain & Loss of range of motion \\
\hline 1 & $36 / \mathrm{M}$ & No impairment & Nil & $15^{\circ}$ \\
\hline 2 & 28/M & No impairment & Nil & $10^{\circ}$ \\
\hline 3 & $30 / / \mathrm{M}$ & No impairment & Nil & $10^{\circ}$ \\
\hline 4 & $35 / F$ & No impairment & Nil & $0^{\circ}$ \\
\hline 5 & 40/M & No impairment & Nil & $0^{\circ}$ \\
\hline 6 & $36 / \mathrm{M}$ & No impairment & Nil & $5^{\circ}$ \\
\hline 7 & $27 / F$ & No impairment & Nil & $5^{\circ}$ \\
\hline 8 & 42/M & Mild impairment in activities & Mild & $30^{\circ}$ \\
\hline 9 & $38 / \mathrm{M}$ & No impairment & Nil & $10^{\circ}$ \\
\hline 10 & $35 / F$ & No impairment & Nil & $15^{\circ}$ \\
\hline 11 & $55 / F$ & Mild impairment in activities & Mild & $30^{\circ}$ \\
\hline 12 & 29/M & Mild impairment in activities & Moderate & $40^{\circ}$ \\
\hline 13 & $35 / \mathrm{M}$ & No impairment & Nil & $5^{\circ}$ \\
\hline 14 & $30 / \mathrm{M}$ & No impairment & Nil & $10^{\circ}$ \\
\hline 15 & $38 / \mathrm{M}$ & No impairment & Nil & $15^{\circ}$ \\
\hline 16 & 40/M & No impairment & Nil & $5^{\circ}$ \\
\hline 17 & $35 / \mathrm{M}$ & No impairment & Nil & $10^{\circ}$ \\
\hline
\end{tabular}

\section{TABLE 3: Friedman-Wyman scoring of individual patients}

$\mathrm{M}=$ male $; \mathrm{F}=$ female

\begin{tabular}{|l|l|}
\hline \hline & Score \\
\hline Excellent & $90-100$ \\
\hline Good & $80-89$ \\
\hline Fair & $70-79$ \\
\hline Poor & $<70$ \\
\hline TABLE 4: Harris Hip Score & \\
\hline \hline
\end{tabular}

Figure 4 shows the range of motion of the patient at the one-year follow-up. 


\section{Cureus}

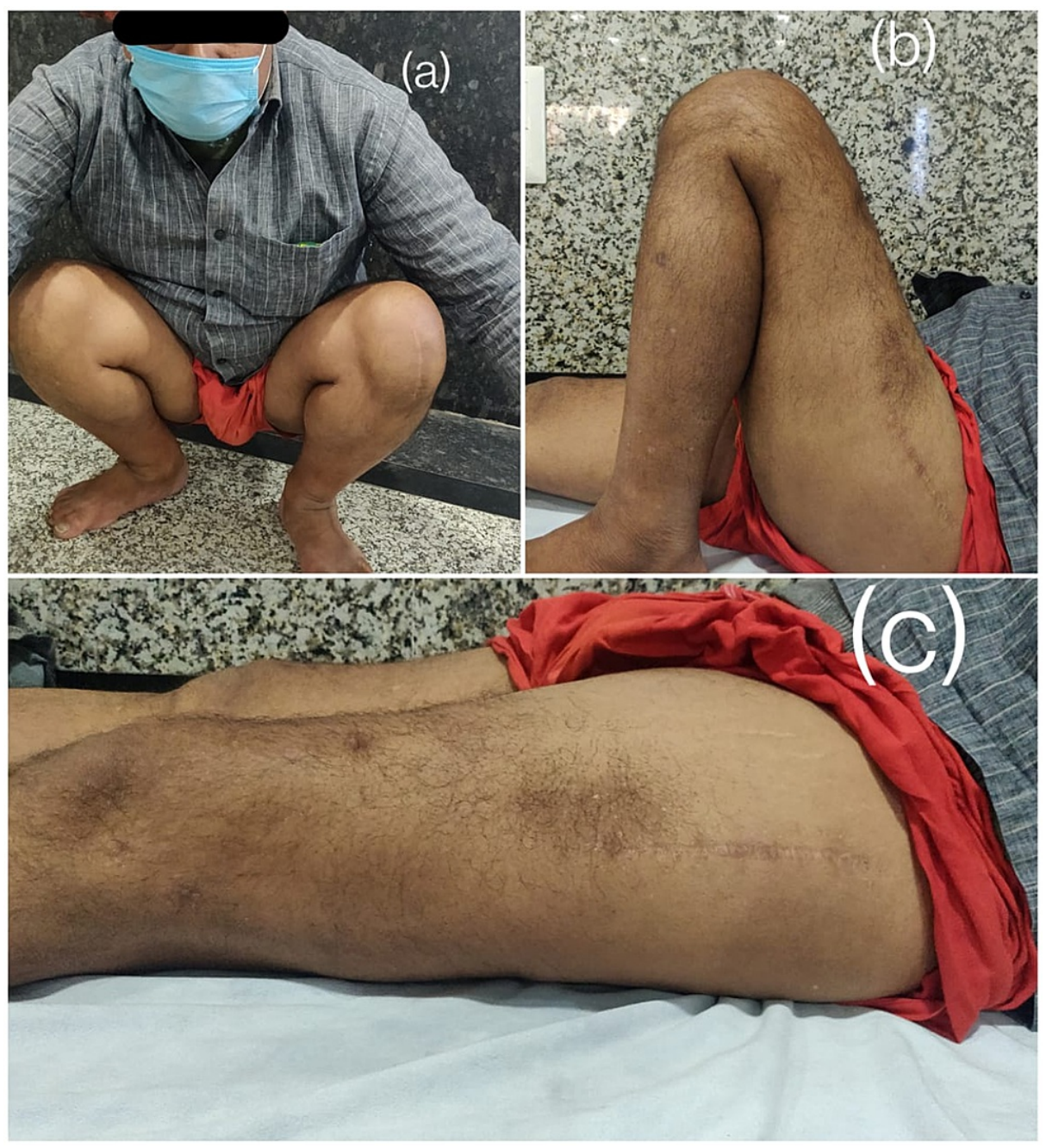

\section{FIGURE 4: Clinical photographs showing the functional outcome at the one-year follow-up}

(a) Patient comfortably sitting in a squatting position; (b) flexion at knee; (c) extension at knee

\section{Discussion}

Ipsilateral proximal femur and diaphyseal femur fractures are mostly seen as a result of high-energy trauma. Leung et al. reported 16 such cases with a mean age of 29 years [11]. Mohan et al. did a systematic review of six studies with 173 cases having an average age of 32 years [12]. Chaturvedi and Sahu and Abalo et al. with similar studies had a sample size of 17 and 37 cases with a mean age of 22-36 years and 37 years,

respectively $[13,14]$. von Rüden et al. and Singh et al. did comparative studies over treatment of multilevel ipsilateral femoral fractures and studied 65 and 27 cases with an average age of 45 and 35 years, respectively $[1,8]$. We studied 17 patients whose mean age was around 35.8 years that indicates that the incidence of such fractures due to high-energy trauma is mostly in the third and fourth decades of life.

Most of the literature regarding this fracture has measured the functional outcome using the FriedmanWyman score [9]. Mohan et al. in a systematic review of six studies compared the functional outcome of managing such fractures by single versus separate implants and $79.4 \%$ had a good outcome in the single implant group while $75 \%$ had a good functional outcome in fractures managed by separate implants [12]. In a similar study by Leung et al., functional outcome was measured similarly and $87.5 \%$ had a good outcome while $12.5 \%$ had a fair outcome [11]. Abalo et al. evaluated the outcome of managing ipsilateral femur neck and shaft fracture by the dynamic hip screw and dynamic compression plate and found $78 \%$ had good, $13.5 \%$ had fair and $8.5 \%$ had poor functional outcomes [14]. Singh et al. did a comparative study of managing multilevel ipsilateral shaft femoral fractures using two different methods: one group with the single intramedullary nail and other group with two plate combinations and found no significant differences in the functional outcome of both the groups [8]. Wang et al. in a similar comparative study compared one group of patients managed by long proximal femoral nail antirotation (PFNA) with another group managed by plate combinations and found no significant difference in the functional outcome of both the groups [15]. In our 
study of dual implant osteosynthesis in such fractures, we found $82.3 \%$ patients had a good functional outcome and $17.6 \%$ had a fair outcome.

Abalo et al. studied surgical outcomes in 37 patients with ipsilateral femur shaft and femur neck fractures managed by separate implants and found that $92 \%$ neck femur fractures united in an average of four months while $87 \%$ of shaft femur fractures united within six months [14]. Mohan et al. did a meta-analysis of six non-randomized cohort studies assessing 173 patients and found that due to lack of randomized studies, it was difficult to recommend a single or separate device treatment approach and that more prospective randomized studies were needed on the topic to come to a proper consensus [12]. Chaturvedi and Sahu treated 17 cases with concomitant fractures of the ipsilateral shaft and neck and the time of union for neck fractures was an average of four months and the time of union for shaft femoral fractures was an average of three months two weeks [13]. Singh et al. did a comparative study of managing multilevel ipsilateral shaft femoral fractures using two different methods: one group using a single intramedullary nail and other group with two plate combinations, and found no significant difference in both the groups regarding the time taken for bone union [8]. In our study, the average time of union of the proximal femur fracture was 5.05 months and the average time of union for the shaft femoral fracture was 6.5 months.

In our study, we first stabilized the distal shaft fracture and fixed the neck or intertrochanteric fracture afterwards. The limitations of the present study include the small number of patients and the potential for user bias, because the surgeon could not be blinded with respect to the method used. Also, the overall cost of surgery and the time for surgery increase as two implants have to be used. Two different incisions have to be used that is another limitation regarding this procedure. These limitations notwithstanding, this prospective study showed that this treatment method is a reliable option in the management of ipsilateral proximal femoral and shaft fractures.

\section{Conclusions}

Dual implant osteosynthesis offers a biomechanically improved management of ipsilateral femur shaft and proximal femur fractures and addresses both fractures separately thus providing the bone union. Although we would like to encourage the use of dual implants for satisfactory functional and clinical outcome in the management of these types of fractures, we suggest more studies with longer follow-ups, multiple blinding, greater sample size, control groups and comparisons to come to a proper consensus to be followed methodically for such surgically challenging fractures.

\section{Additional Information \\ Disclosures}

Human subjects: Consent was obtained or waived by all participants in this study. Institute Ethics Committee issued approval Dean/2019/EC/1440. This study named "Outcome Analysis of Dual Implant Osteosynthesis for Ipsilateral Proximal and Shaft Femur Fracture: Do We Need Cephalomedullary Nails?" is approved by the Institute Ethics Committee. Animal subjects: All authors have confirmed that this study did not involve animal subjects or tissue. Conflicts of interest: In compliance with the ICMJE uniform disclosure form, all authors declare the following: Payment/services info: All authors have declared that no financial support was received from any organization for the submitted work. Financial relationships: All authors have declared that they have no financial relationships at present or within the previous three years with any organizations that might have an interest in the submitted work. Other relationships: All authors have declared that there are no other relationships or activities that could appear to have influenced the submitted work.

\section{References}

1. von Rüden C, Tauber M, Woltmann A, Friederichs J, Hackl S, Bühren V, Hierholzer C: Surgical treatment of ipsilateral multi-level femoral fractures. J Orthop Surg Res. 2015, 10:7. 10.1186/s13018-014-0149-5

2. Alho A: Concurrent ipsilateral fractures of the hip and shaft of the femur. A systematic review of 722 cases . Ann Chir Gynaecol. 1997, 86:326-336.

3. Haas NP, Schütz M, Mauch C, Hoffmann R, Südkamp NP: Management of ipsilateral fractures of the femur shaft and proximal femur--therapy overview and current management. (Article in German). Zentralbl Chir. 1995, 120:856-861.

4. Gadegone W, Lokhande V, Salphale Y, Ramteke A: Long proximal femoral nail in ipsilateral fractures proximal femur and shaft of femur. Indian J Orthop. 2013, 47:272-277.

5. Swiontkowski MF, Hansen ST Jr, Kellam J: Ipsilateral fractures of the femoral neck and shaft. A treatment protocol. J Bone Joint Surg Am. 1984, 66:260-268.

6. Schatzker J, Barrington TW: Fractures of the femoral neck associated with fractures of the same femoral shaft. Can J Surg. 1968, 11:297-305

7. Wiss DA, Sima W, Brien WW: Ipsilateral fractures of the femoral neck and shaft . J Orthop Trauma. 1992, 6:159-166. 10.1097/00005131-199206000-00005

8. Singh R, Rohilla R, Magu NK, Siwach R, Kadian V, Sangwan SS: Ipsilateral femoral neck and shaft fractures: a retrospective analysis of two treatment methods. J Orthop Traumatol. 2008, 9:141-147. 10.1007/s10195008-0025-3

9. Mahomed NN, Arndt DC, McGrory BJ, Harris WH: The Harris hip score: comparison of patient self-report 


\section{Cureus}

with surgeon assessment. J Arthroplasty. 2001, 16:575-580. 10.1054/arth.2001.23716

10. Friedman RJ, Wyman ET Jr: Ipsilateral hip and femoral shaft fractures . Clin Orthop Relat Res. 1986, 188194.

11. Leung KS, So WS, Lam TP: Treatment of ipsilateral femoral shaft fractures and hip fractures . Injury. 1993, 24:41-45. 10.1016/0020-1383(93)90082-h

12. Mohan K, Ellanti P, French H, Hogan N, McCarthy T: Single versus separate implant fixation for concomitant ipsilateral femoral neck and shaft fractures: a systematic review. Orthop Rev (Pavia). 2019, 11:7963. 10.4081/or.2019.7963

13. Chaturvedi S, Sahu SC: Ipsilateral concomitant fractures of the femoral neck and shaft . Injury. 1993, 24:243246. 10.1016/0020-1383(93)90178-9

14. Abalo A, Dossim A, Ouro Bangna AF, Tomta K, Assiobo A, Walla A: Dynamic hip screw and compression plate fixation of ipsilateral femoral neck and shaft fractures. J Orthop Surg (Hong Kong). 2008, 16:35-38. $10.1177 / 230949900801600109$

15. Wang WY, Liu L, Wang GL, Fang Y, Yang TF: Ipsilateral basicervical femoral neck and shaft fractures treated with long proximal femoral nail antirotation or various plate combinations: comparative study. J Orthop Sci. 2010, 15:323-330. 10.1007/s00776-010-1468-y 